\title{
Metal Ions Released from Fixed Orthodontic Appliance Affect Hair Mineral Content
}

\author{
Marcin Mikulewicz • Paulina Wołowiec • Bartlomiej Loster • \\ Katarzyna Chojnacka
}

Received: 18 August 2014 / Accepted: 6 October 2014 / Published online: 19 October 2014

(C) The Author(s) 2014. This article is published with open access at Springerlink.com

\begin{abstract}
The objective was to evaluate metal ion accumulation in hair of patients undergoing orthodontic treatment with fixed appliances in time. The patients $(N=47)$ participated in a questionnaire survey. Hair sampling was performed at the beginning and in the 4 th, 8 th, and 12 th month of the treatment. The content of metals $(\mathrm{Cr}, \mathrm{Ni}, \mathrm{Fe})$ in hair was analyzed by ICP-OES equipped with USN nebulizer. The peak release of $\mathrm{Cr}$ and Fe occurred after 4 months of the treatment, and the peak release of $\mathrm{Ni}$ gradually increased throughout the whole year of the therapy. During 1 year treatment, an average accumulation of metals in hair tissue was $7.42 \pm 14.19 \mu \mathrm{g}$ of $\mathrm{Ni}, 8.94 \pm 13.1 \mu \mathrm{g}$ of $\mathrm{Cr}$, and $131 \pm 279 \mu \mathrm{g}$ of Fe. The mean content of $\mathrm{Cr}$ was higher than the 90th percentile value for this element. The upper limit of literature reference ranges for $\mathrm{Cr}$, $\mathrm{Ni}$, and $\mathrm{Fe}$ in hair was not exceeded. The value of exposure (kinetics and dose) of orthodontic patients to metal ions released from orthodontic appliances can be assessed by hair mineral analysis. The content of $\mathrm{Cr}$ was statistically
\end{abstract}

\footnotetext{
M. Mikulewicz $(\square)$

Department of Dentofacial Orthopaedics and Orthodontics, Division of Facial Abnormalities, Medical University of Wrocław, Krakowska 26, Wrocław 50-425, Poland

e-mail: mikulewicz.marcin@gmail.com

P. Wołowiec $\cdot$ K. Chojnacka

Institute of Inorganic Technology and Mineral Fertilizers, Wrocław

University of Technology, Wrocław, Poland

P. Wołowiec

e-mail: paulina.wolowiec@pwr.wroc.pl

K. Chojnacka

e-mail: katarzyna.chojnacka@pwr.wroc.pl

B. Loster

Department of Orthodontics, Medical College, Jagiellonian

University, Wrocław, Poland

e-mail: bwloster@gmail.com
}

significantly higher during the treatment than before the beginning of therapy.

Keywords Chromium - Fixed orthodontic appliance . Hair mineral analysis $\cdot$ Kinetics $\cdot$ Nickel

\section{Introduction}

An increasing demand for biocompatibility testing of medical devices has led to the application of different evaluation methods. In contemporary dentistry, applied materials are being introduced to the market and frequently one material promptly replaces another, which entails questions about long-term biocompatibility [1]. Of invasive and non-invasive accessible biomarkers of exposure, the latter seem to be the most practical. Hair mineral analysis as a biomarker has been used for several years [2]. The collected material is digested and after solubilization undergoes multielemental analysis by various spectroscopic techniques (e.g., ICP-OES (inductively coupled plasma-optical emission spectroscopy), ICP-MS (inductively coupled plasma-mass spectroscopy), AAS (atomic absorption spectroscopy)). The sensitivity of the instruments enables determination of elements even at trace levels [3].

Usually, orthodontic treatment with fixed appliances lasts for approximately 2-3 years. Most of the patients are youngsters or adolescents. Some parts of a removable appliance and all parts of a fixed appliance are manufactured from alloys which contain, inter alia, nickel and chromium [4]. Those metals are well known as sensitizing and mutagenic agents $[5,6]$. This shows that it is important to assess biocompatibility of orthodontic appliances.

In the evaluation of biocompatibility of materials used in orthodontics, chemical techniques are indispensable. In order to assess the real exposure of patients to the chemical elements 
released from metal alloys, tests on patients undergoing orthodontic therapy are essential. This enables monitoring side effects of orthodontic treatment, in particular the exposure to the products of corrosion of stainless steel. In the current literature, the studies on the release of metal ions concern in vitro [7] and in vivo: saliva [8, 9], blood [10], epithelium cells [11, 12], urine [13], and hair [14] were reported. The content of the elements in various matrices reflects different windows of detection: for urine and saliva (36-72 h, the measure of acute exposure), which is similar as for blood [2]. Since patients experience pain as blood and epithelium cells are being sampled, it is difficult to meet the monitoring study requirements [15]. Element levels in hair reflect a longterm (chronic) exposure, and the quantity of excreted elements by this route can be considered as an indirect measure of exposure [16]. In a long-term exposure (which is the case of orthodontic treatment), the question how to select the best biomarker for the specific clinical situation arises. Because of the wide window of detection, the concept of using hair as a non-invasive matrix to investigate the release of metal ions from orthodontic appliance seems to be reasonable [2].

The objective of the present work was to evaluate metal ions released to human hair in patients undergoing orthodontic treatment with fixed appliances in time.

\section{Materials and Methods}

Research was performed in accordance with the principles laid down in the Helsinki Declaration. The study was carried out with the approval of the Ethical Committee of Wroclaw Medical University (KB-400/2010). The material (hair) was collected from a group of 47 patients (volunteers) (31 females, 16 males; average age was $17.2 \pm 6.6$ years; the minimum age was 11 and the maximum was 31), treated at the Orthodontic Department of the Faculty of Medicine, the Jagiellonian University in Cracow, Poland. The patients signed the agreement to participate in the study. The inclusion criteria for the study were lack of previous orthodontic treatment and generally good health. Patients were treated with the use of a full (upper and lower arch) orthodontic fixed appliance: brackets (Victory series; SS, 3M Unitek, Monrovia, Calif, USA), bands (SS, 3M Unitek, Monrovia, Calif, USA), and wires (NiTi, SS, 3M Unitek, Monrovia, Calif, USA). The sampling strategy was as follows: before the treatment (as a control) and on 4th, 8th, and 12th month of the treatment (average sampling interval $4.14 \pm 1.87$ months). The patients were instructed on how to collect the samples (3-4 cm of the hair strand measured from the scalp was sampled, shortly after the hair had been washed). Each patient received a sample container and a shampoo (baby shampoo, containing no functional components). It was explained to the patients that the meaningful and interpretable result of the hair mineral analysis could only be obtained when the specified procedures for washing hair were complied with.

\section{Questionnaire Survey}

Before the treatment, the patient and the orthodontist were asked to fill out the electronic questionnaire: the patient about his lifestyle and possible sources of exposure, the orthodontist about the types of used appliances. The questionnaire included questions on lifestyle habits: general information (age, sex), hair (type, color), medical history, supplementation (vitaminmineral preparations), dietary habits (fruits, vegetables, meat, fish, mushrooms), environmental exposure (place of living), and others (smoking, jewelry). This enabled pointing out the sources of exposure to toxic metals and identifying the sources of exposure stemming from the patient's diet.

The material was sent (the hair samples were coded) to a specialized laboratory where hair samples underwent purification from organic components and multielemental analyses by ICP-OES.

\section{Analytical Methods}

The samples $(0.5 \mathrm{~g})$ were decomposed with concentrated nitric acid $-69 \%(\mathrm{~m} / \mathrm{m})(5 \mathrm{~mL})$, spectrally pure (Suprapur,

Table 1 Contents of elements in hair samples, $\mathrm{mg} / \mathrm{kg}$

\begin{tabular}{|c|c|c|c|c|c|c|c|c|c|c|c|c|}
\hline \multirow[t]{3}{*}{ Metal } & \multicolumn{3}{|l|}{ Hair I } & \multicolumn{3}{|l|}{ Hair II } & \multicolumn{3}{|l|}{ Hair III } & \multicolumn{3}{|l|}{ Hair IV } \\
\hline & \multicolumn{3}{|l|}{$N=47$} & \multicolumn{3}{|l|}{$N=47$} & \multicolumn{3}{|l|}{$N=45$} & \multicolumn{3}{|l|}{$N=39$} \\
\hline & Mean & SD & Median & Mean & SD & Median & Mean & SD & Median & Mean & $\mathrm{SD}$ & Median \\
\hline $\mathrm{Cr}$ & $0.0201^{\mathrm{a}, \mathrm{b}, \mathrm{A}}$ & 0.0430 & 0.00100 & $0.184^{\mathrm{a}}$ & 0.326 & 0.0218 & $0.179^{\mathrm{A}}$ & 0.291 & 0.0284 & $0.158^{\mathrm{b}}$ & 0.287 & 0.00717 \\
\hline $\mathrm{Ni}$ & 0.288 & 0.334 & 0.198 & 0.366 & 0.418 & 0.217 & 0.320 & 0.381 & 0.206 & 0.422 & 0.483 & 0.345 \\
\hline $\mathrm{Fe}$ & 10.3 & 4.3 & 9.301 & 14.9 & 19.3 & 12.0 & 13.1 & 15.7 & 10.4 & 14.2 & 14.3 & 10.3 \\
\hline
\end{tabular}

Hair I - before the treatment, Hair II — 4th month of the treatment, Hair III -8 th month, Hair IV -12 th month

Analysis of variance with repeated measurements, Tukey test: ${ }^{\mathrm{A}}(p \leq 0.05),{ }^{\mathrm{a}, \mathrm{b}}(p \leq 0.1)$ 
Merck, Darmstadt, Germany), in Teflon bombs in the Milestone Start D microwave oven (Sorisole, Italy). Such parameters of decomposition were selected as to achieve the complete mineralization of the samples. After mineralization, the samples were diluted with double demineralized water (Millipore Simplicity, Molsheim, France) to 50 g. Next, multielemental analyses by ICP-OES Varian-Vista MPX (Australia) with ultrasonic nebulizer CETAC U5000AT+ were performed. The analyses were carried out in the quality management system (PN-EN ISO/IEC 17025:2005; accreditation number AB 696 PL PCA). The analyses were repeated three times. The quality control of the analytical process was achieved by the application of Certified Reference Material -Human Hair NCS ZC81002 (China National Analysis Centre). All the hair samples were sent to the laboratory in one batch and analyzed together under a single calibration. Single element laboratory standards from Ultra Scientific were used for determination of $\mathrm{Cr}, \mathrm{Fe}$, and $\mathrm{Ni}$. The calibration curve included the following concentrations: $0.01,0.025$, $0.05,0.1,0.5,1$, and $5 \mathrm{mg} / \mathrm{L}$. The laboratory used quality control procedures according to the implemented Quality Assurance System.

\section{Estimated Hair Mass Growth Rate}

An adult has approximately 100,000 hairs on the scalp [17], and the average growth rate is $1 \mathrm{~cm} /$ month [2]. It was calculated that $1 \mathrm{~cm}$ of single hair of a Caucasian individual has a mass of $0.0518 \mathrm{mg}$ (200 hairs with the length of $10 \mathrm{~cm}$ were weighed). Estimated hair mass growth rate was $5.18 \mathrm{~g} / \mathrm{month}$, as shown by the following equation:

$$
\begin{aligned}
r_{\text {hair }}\left(\frac{g}{\text { month }}\right)= & r_{\text {hair }}\left(\frac{\mathrm{cm}}{\text { month }}\right) \times \text { hair count }(100,000) \\
& \times m_{(1 \mathrm{~cm} \mathrm{hair})}(0.0518 \mathrm{mg})
\end{aligned}
$$

where

$r_{\text {hair }} \quad$ Rate of hair growth

hair count The average number of hair on human head

$m_{(1 \mathrm{~cm} \text { hair) }}$ The average mass of a single hair strand, 1-cm length

Hair mass growth rate was calculated to determine the mass of nickel/chromium/iron accumulated in hair tissue during 1 month. The rate of hair growth $(\mathrm{kg} /$ month) was multiplied per the content of element $(\mathrm{mg} / \mathrm{kg})$, yielding the rate of accumulation (mg/month).

\section{Statistical Methods}

The results were elaborated statistically in Statistica ver. 10.0. Descriptive statistics (means, standard deviations, and medians) were reported. Normality of distribution of the results was investigated by the Shapiro-Wilk test. Statistical tests were performed by the analysis of the variance with repeated measurements. The ANOVA analysis was performed to determine the expected equivalent boundary, with the

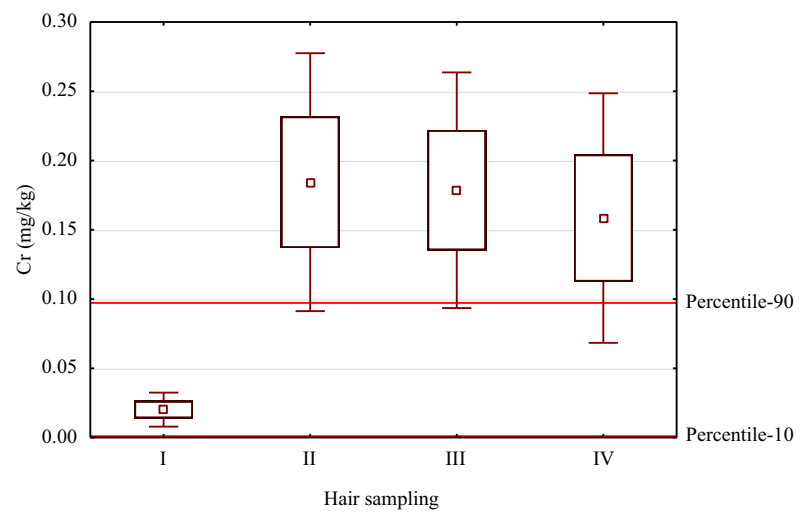

Mean

$\square$ Mean \pm Std. Err.

I Mean $\pm 1.96 *$ Std. Err.

(a)

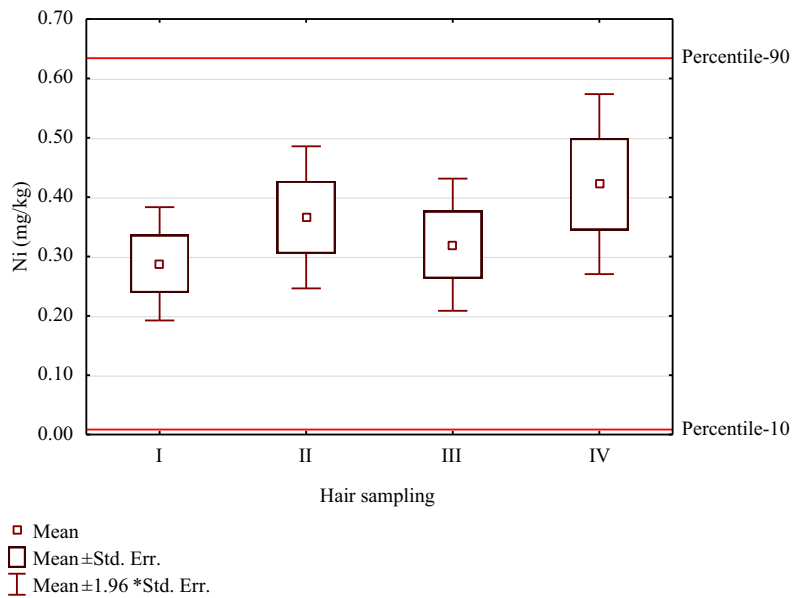

(b)

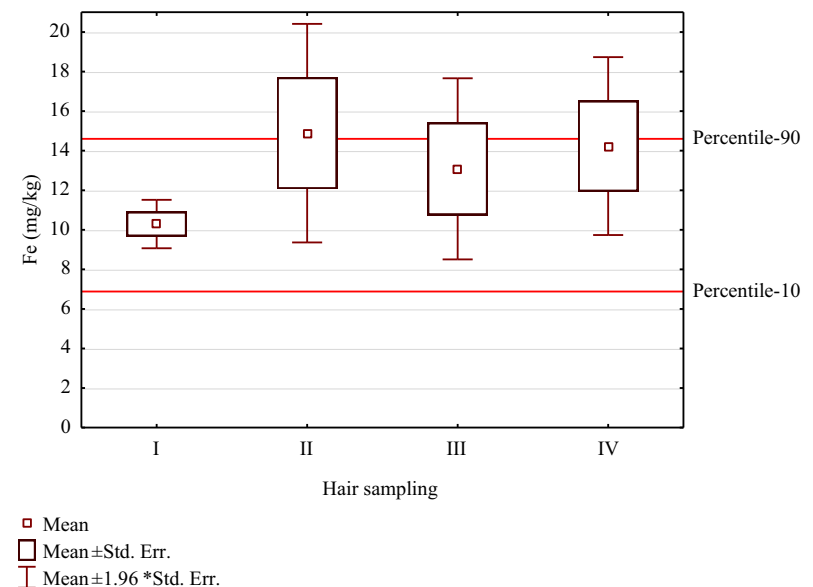

(c)

Fig. 1 The content of $\mathbf{a ~} \mathrm{Cr}, \mathbf{b} \mathrm{Ni}$, and $\mathbf{c} \mathrm{Fe}$ in hair of patients in time during 1 year of orthodontic treatment 
statistical significance set at $p \leq 0.05$ and significance being $p \leq$ 0.1 . Then, a post hoc analysis was undertaken with the Tukey test for the groups of different samplings as the effect. The non-parametric Mann-Whitney $U$ test was used to investigate the effect of the questionnaire survey on the level of $\mathrm{Cr}$ and $\mathrm{Ni}$ in hair before the beginning of treatment. The statistically significant parameters were considered in a multiple regression analysis. Statistical significance was set at $p \leq 0.1$.

\section{Results}

The power test analysis was performed by univariate analysis of variance. The purpose of this analysis was to compare the mean value of four independent groups of results. Thus, the hypothesis of their equality was tested and confirmed. Univariate analysis of variance was performed at the level of type I error $(\alpha)$ equal to 0.05 . It was assumed that root-meansquare standardized effect (RMSSE) in the population was 0.29008 . For the sample size used $(N=47)$ in the experiment, at the level of significance set at $0.5 \%$, the power of the test was $82.70 \%$. The test was considered strong.

The sample loss during the experiment was $17 \%$ (8 patients). The content of $\mathrm{Ni}$ and $\mathrm{Cr}$ substantially increased during the treatment (Table 1), in particular during the first months after the insertion of orthodontic appliance. The differences were statistically significant for $\mathrm{Cr}$. For $\mathrm{Ni}$ and $\mathrm{Fe}$, they were not statistically significant (Fig. 1). The ranges between 10th and 90th percentile for the studied group, before the beginning of the orthodontic treatment, were evaluated (Table 2) and marked on Fig. 1. Table 1 shows that there were no statistically significant differences for $\mathrm{Ni}$, although the content of this element increased over $46 \%$ in the final sampling.

On the basis of probability $p$, it was evaluated whether the distribution of the variable $(\mathrm{Cr}, \mathrm{Fe}$, and $\mathrm{Ni}$ content) can be considered normal. In our case, $p=0.0000$ was less than the significance level $\alpha=0.05$; therefore, the hypothesis of the normal distribution of results was rejected. The data were $\log$ transformed, which also yielded a not normal distribution. Consequently, a non-parametric test was used to identify the significance of the results. Table 2 shows median values. Mean values and standard deviations were given for information. For Cr, the median was set at the level of $0.00100 \mathrm{mg} / \mathrm{kg}$ because before the orthodontic treatment in 33 out of 47 samples, the content in the analyzed sample was below the lower limit of detection (LLD; Table 2). After the treatment, the content of $\mathrm{Cr}$ substantially increased.

The statistical significance of differences was found for $\mathrm{Cr}$ between the samplings. After 4 months of the treatment, the content of $\mathrm{Cr}$ increased over nine times and then gradually decreased. The explanation could be the formation of the oxide layer which protects from further release. The decrease in the level of $\mathrm{Cr}$ in hair might result from previous detoxication. The differences were statistically significant. The release of $\mathrm{Ni}$ to human hair tissue was not as strong: a $27 \%$ increase after 4 months, $46 \%$ after 1 year. Fe is the main component of stainless steel; however, it is not of toxicological concern. The increase in Fe level was by $45 \%$ during 4 months, with the decrease over time being down to $38 \%$ after 12 months.

The mass of released $\mathrm{Cr}, \mathrm{Ni}$, and $\mathrm{Fe}$ ions that was transferred to hair tissue was calculated on the basis of empirically determined hair mass growth rate $(5.18 \mathrm{~g} /$ month $)$. This
Table 2 Contents of chromium and nickel in hair collected before treatment, $\mathrm{mg} / \mathrm{kg}$

Mann-Whitney $U$ test was used

\begin{tabular}{lccccc}
\hline & Mean & SD & Median & $10-90$ Percentile & $p$ \\
\hline Cr & & & & & \\
$\quad$ Total, $N=47$ & 0.0201 & 0.0430 & 0.00100 & $0.00100-0.09719$ & - \\
$\quad$ Females, $N=31$ & 0.0212 & 0.0422 & 0.00100 & $0.00100-0.09719$ & 0.907 \\
$\quad$ Males, $N=16$ & 0.0178 & 0.0465 & 0.00100 & $0.00100-0.02910$ & \\
$\quad<18$ years, $N=30$ & 0.0210 & 0.0436 & 0.00100 & $0.00100-0.11439$ & 0.842 \\
$>18$ years, $N=17$ & 0.0187 & 0.0433 & 0.00100 & $0.00100-0.04946$ & \\
Ni & & & & & \\
$\quad$ Total, $N=47$ & 0.275 & 0.325 & 0.197 & $0.00843-0.57395$ & - \\
Females, $N=31$ & 0.300 & 0.373 & 0.197 & $0.00945-0.57395$ & 0.954 \\
$\quad$ Males, $N=16$ & 0.220 & 0.166 & 0.205 & $0.00500-0.41510$ & \\
$\quad<18$ years, $N=30$ & 0.312 & 0.330 & 0.230 & $0.0423-0.6038$ & 0.994 \\
$>18$ years, $N=17$ & 0.211 & 0.316 & 0.144 & $0.00616-0.41510$ & \\
Fe & & & & & - \\
$\quad$ Total, $N=47$ & 13.2 & 14.6 & 10.4 & $6.31-18.4$ & - \\
Females, $N=31$ & 9.90 & 3.01 & 9.34 & $6.88-13.0$ & - \\
$\quad$ Males, $N=16$ & 11.6 & 6.28 & 9.14 & $7.13-20.8$ & \\
$\quad<18$ years, $N=30$ & 10.9 & 5.19 & 9.19 & $6.81-20.1$ & \\
$>18$ years, $N=17$ & 9.74 & 2.11 & 9.34 & $7.13-12.8$ & \\
\hline
\end{tabular}


enabled us to determine the mass of $\mathrm{Cr}, \mathrm{Ni}$, and $\mathrm{Fe}$ excreted to hair of an individual patient, as compared to the mass at the starting point of the therapy within sampling intervals (Fig. 2),

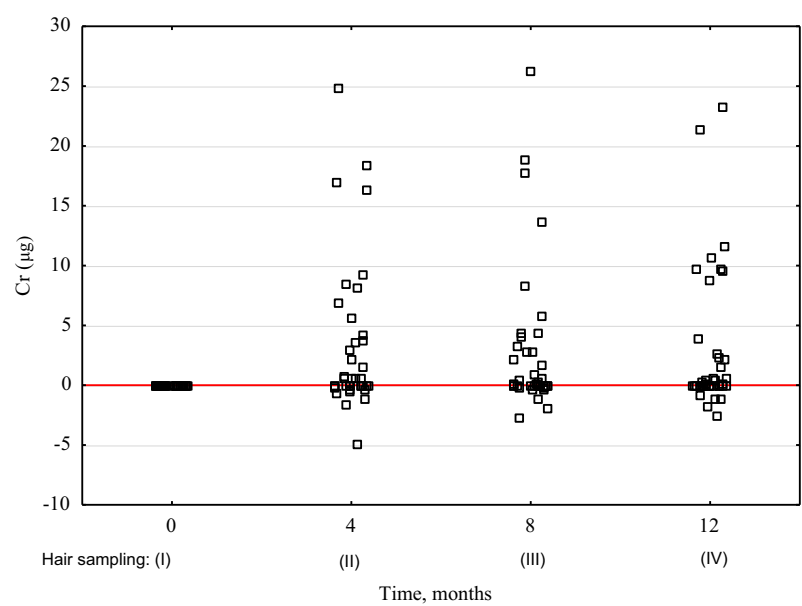

(a)

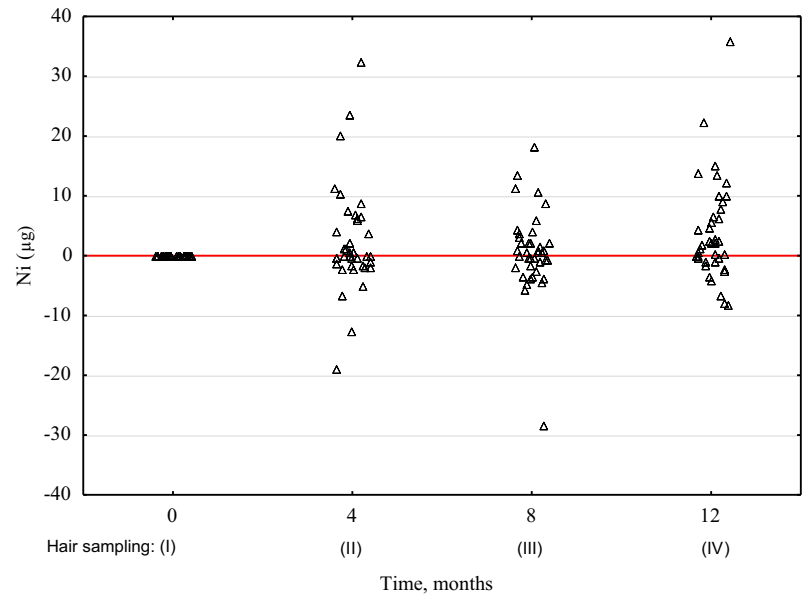

(b)

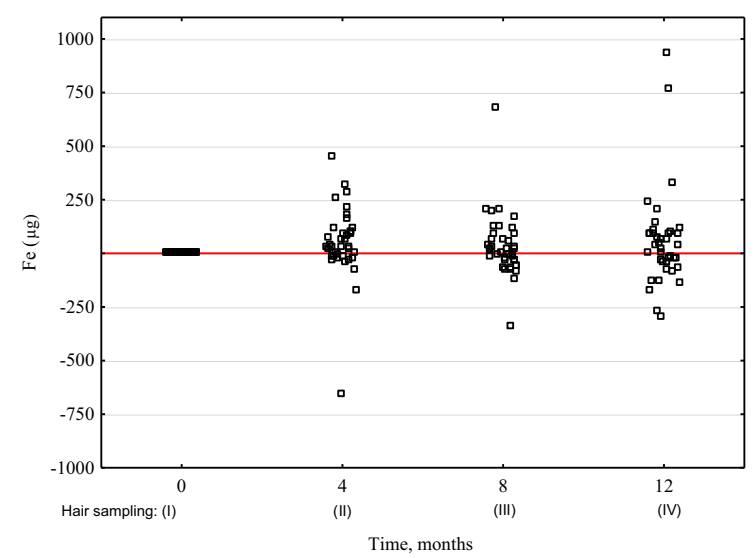

(c)

Fig. 2 Accumulation of $\mathbf{a} \mathrm{Cr}, \mathbf{b} \mathrm{Ni}$, and $\mathbf{c} \mathrm{Fe}$ after 1 year of orthodontic treatment in hair tissue of patients in time (as related to sampling I of individual patients) as well as to the accumulation after 1 year of orthodontic treatment in hair (Table 3, Fig. 3).

The accumulation after 1 year of orthodontic treatment ( $m_{12}$ months) was described with the following equation:

$$
\begin{aligned}
m_{12 \text { months }}= & \frac{\left(C_{\mathrm{II}}-C_{\mathrm{I}}\right) \cdot r_{\text {hair }}\left(\frac{\mathrm{g}}{\text { month }}\right)}{\text { time }(4 \text { months })} \\
& +\frac{\left(C_{\mathrm{III}}-C_{\mathrm{II}}\right) \cdot r_{\text {hair }}\left(\frac{\mathrm{g}}{\text { month }}\right)}{\operatorname{time}(4 \text { months })} \\
& +\frac{\left(C_{\mathrm{IV}}-C_{\mathrm{III}}\right) \cdot r_{\text {hair }}\left(\frac{\mathrm{g}}{\text { month }}\right)}{\text { time }(4 \text { months })}\left(\frac{\mathrm{mg}}{12 \text { months }}\right)
\end{aligned}
$$

where

$m_{12}$ months is the accumulation of metal ions after 1 year of orthodontic treatment.

This mass is referring to the sum of all measurements in 4month intervals, as referred to the previous. Baseline plotted at $m_{\mathrm{Cr}, \mathrm{Ni}, \mathrm{Fe}}=0 \mu \mathrm{g}$ on Fig. 2 signifies no accumulation. In some patients, the level of measured elements was reduced, which was probably related with individual exposure from other sources. For the majority of patients (41 out of 47 patients for $\mathrm{Cr}, 34$ for Ni, 33 for $\mathrm{Fe}$ ), an orthodontic appliance was an additional source of exposure to these elements (Fig. 3).

Multiple regression analyses with the use of all statistically significant factors were conducted for $\mathrm{Ni}$ and $\mathrm{Cr}$. It was found that, among the selected variables, only sampling as a grouping variable was statistically significant for $\mathrm{Cr}$.

\section{Discussion}

Hair mineral analysis is widely used in the determination of human chronic exposure to various elements, among them toxic metals. Analysis of elements in hair tissue is a noninvasive biomarker of exposure. Sampling and storage of the material is easy and sensitivity of analytical techniques has been recently improved. Although orthodontic treatment is an example of chronic exposure, there is little scientific literature on the subject of hair mineral analysis in the context of metal ions released from orthodontic appliances $[14,18,19]$.

Table 3 Released mass of chromium, nickel, and iron after 1 year of the treatment, $\mu \mathrm{g} /$ year $(N=39)$

\begin{tabular}{lcccc}
\hline & Mean & SD & Min & Max \\
\hline $\mathrm{Cr}$ & 8.94 & 13.1 & -4.44 & 42.7 \\
$\mathrm{Ni}$ & 7.42 & 14.19 & -16.7 & 51.9 \\
$\mathrm{Fe}$ & 131 & 279 & -371 & 999 \\
\hline
\end{tabular}




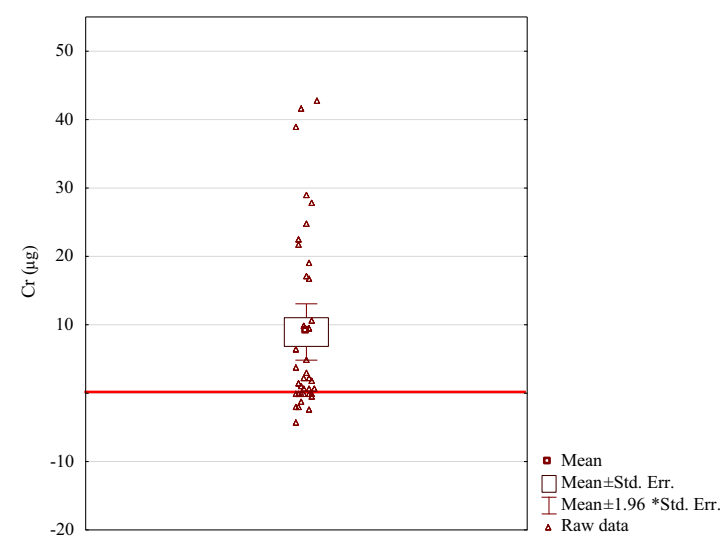

(a)

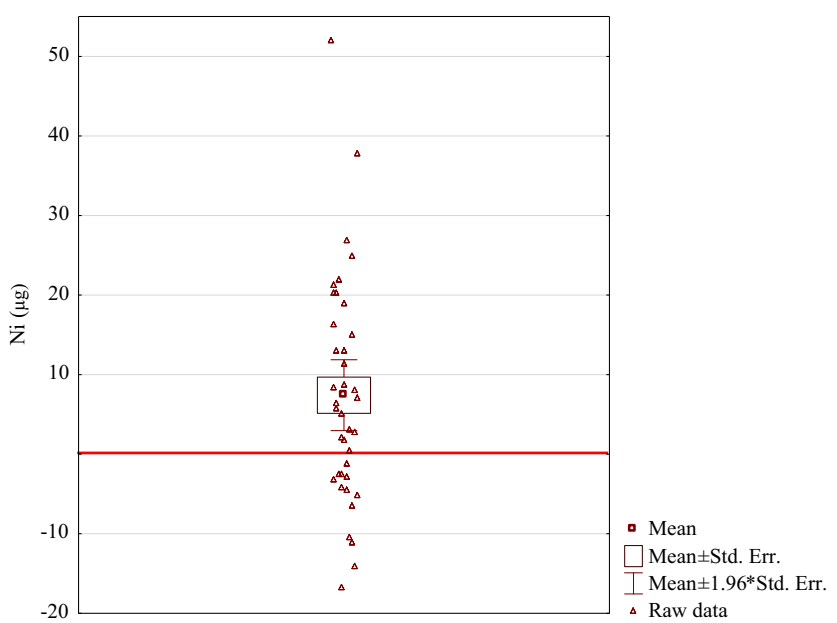

(b)

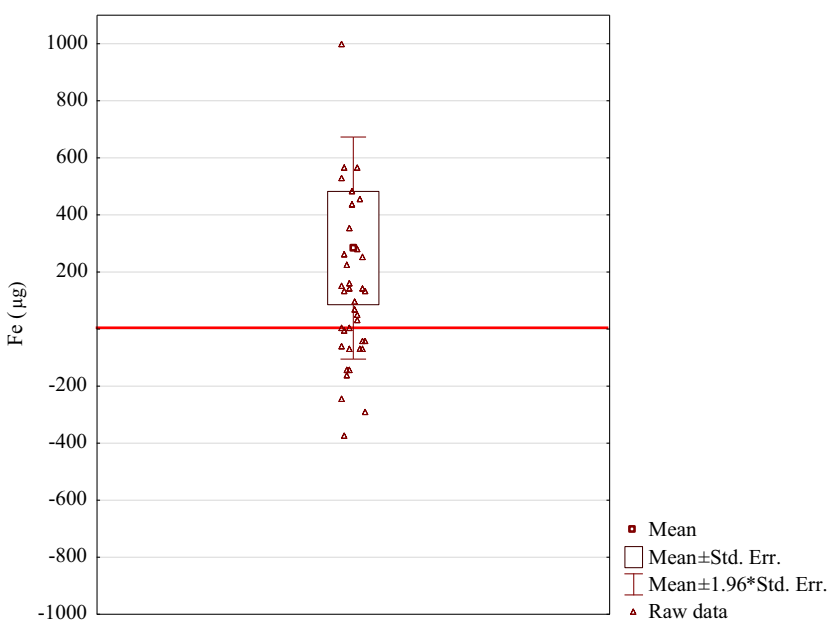

(c)

Fig. 3 Accumulation of $\mathbf{a} \mathrm{Cr}$, $\mathbf{b} \mathrm{Ni}$, and $\mathbf{c} \mathrm{Fe}$ in hair tissue after 12 months of orthodontic treatment

The previous results of study by Mikulewicz et al. [14] demonstrated that the content of the following elements was higher in the group of orthodontic patients $(N=28)$ as compared with the control group $(N=19)$ : $\mathrm{Ni}(39 \%), \mathrm{Mn}(18 \%)$, $\mathrm{Fe}(4.1 \%)$, and $\mathrm{Cr}(2.5 \%)$. It was reported that the upper 90th percentile level of the range for $\mathrm{Ni}$ was $82.5 \%$ higher for orthodontic patients than for the control patients, suggesting that the orthodontic appliance could be the source of a chronic exposure to nickel. The results were not statistically significant [14].

The reference range as the values between the 10th and 90th percentile were determined for the patients before appliance insertion. These values were used as the normal levels of $\mathrm{Cr}, \mathrm{Ni}$, and $\mathrm{Fe}$ in hair. The level of these elements in hair of patients during the treatment was referred to the reference values and served as the measure of the extent of exposure. In the present work, the 90th percentile was exceeded in the experimental groups as compared to the values before the treatment (Cr 560-730\%, Ni 16-28 \%, Fe 20-87\%). The previous study was carried out on the group of patients vs. a control group consisting of other individuals of the same age. In the present work, the control group individuals were the same persons before the treatment which eliminates the problem of individual differences in hair mineral content or exposure to $\mathrm{Ni}$ and $\mathrm{Cr}$ from other sources.

In another study, Levrini et al. [18] reported no increase in the content of $\mathrm{Ni}$ in hair of orthodontic patients as compared to the control group $(0.64$ and $0.50 \mathrm{mg} / \mathrm{kg}$ in control and experimental group, respectively, $N=15$ ). The authors explained that the decrease in the level of $\mathrm{Ni}$ in hair of orthodontic patients was caused by significantly higher absorption of nickel from the diet or environmental exposure, as compared with the quantity of nickel ions released from orthodontic appliances.

In the study performed by Abtahi et al. [19], the release of metal ions was investigated in orthodontic patients (24 females) wearing the appliance for 4 months. The control group individuals in this study were not the same patients but their sisters. The content of nickel in hair statistically significantly $(p=0.002)$ increased from $0.382 \pm 0.36 \mathrm{mg} / \mathrm{kg}$ in the control group to $0.673 \pm 0.38 \mathrm{mg} / \mathrm{kg}$ in the experimental one. Ni ions were released from the orthodontic appliance and were absorbed, distributed, and eliminated by hair tissue. The concentration of the released nickel ions was higher after appliance placement. The content of nickel in hair of orthodontic patients increased ca. $100 \%$ after 4 months of the treatment. In the present work, after 4 months, the results for $\mathrm{Ni}$ were as follows: $0.288 \pm 0.334 \mathrm{mg} / \mathrm{kg}$ in the control group to $0.366 \pm$ $0.418 \mathrm{mg} / \mathrm{kg}$ in the experimental one. The change of the concentration in hair of $\mathrm{Ni}$ ions might be the result of different factors: individual differences in absorption and elimination, dietary habits, and environmental exposure. The differences in Ni concentration between II, III, and IV samplings might be associated with the formation of the passivation layer.

Martin-Camean et al. used hair mineral analysis (AAS method) to monitor the release of $\mathrm{Cr}, \mathrm{Cu}, \mathrm{Fe}, \mathrm{Mn}$, and $\mathrm{Ni}$ in orthodontic patients $(N=70)$ vs. control $(N=56)$. The content of $\mathrm{Cr}$ and $\mathrm{Ni}$ remained unchanged. There was no difference 
between the experimental and the control group: $\mathrm{Cr}(0.36 \pm$ 0.08 and $0.35 \pm 0.26 \mathrm{mg} / \mathrm{kg}$ in the control and experimental group, respectively) and $\mathrm{Ni}(0.47 \pm 0.37,0.46 \pm 0.50 \mathrm{mg} / \mathrm{kg}$, respectively). The content of $\mathrm{Fe}$ decreased (27.24 $17.06 \mathrm{mg} / \mathrm{kg}, 24.97 \pm 15.00 \mathrm{mg} / \mathrm{kg}$ ) [20]. The control group consisted of different persons, suffering from different environmental and dietary exposure, and having different individual characteristics of hair, which might influence the outcomes. In the present work, the control were the same patients, but before the treatment.

The mean values of $\mathrm{Cr}, \mathrm{Ni}$, and $\mathrm{Fe}$ in hair of orthodontic patients in our study were compared to the reference ranges found in the literature on the subject and were found to be below the upper limit [21-23]. In the relevant literature, there are no data on the mass, or dose to which orthodontic patients were exposed. In the present work, the sum of the masses of the $\mathrm{Cr}, \mathrm{Ni}$, and Fe released to hair was measured within 1 year of therapy. The daily masses were respectively as follows: $0.0245,0.0203$, and $0.778 \mu \mathrm{g}$.

The questionnaire survey made it possible to identify confounder factors. The results of the questionnaire survey on the effect of other factors on the level of the investigated elements in hair were analyzed (Table 2). The median values were reported, mean values and SD for the information. It was found that the level of $\mathrm{Cr}$ did not depend on sex neither on age. The questionnaire survey covered also other sources of exposure to $\mathrm{Cr}$ and $\mathrm{Ni}$ (Table 4). This effect was studied on a group before orthodontic treatment. The intake of Coca-Cola increased the level of $\mathrm{Cr}$ three times. Drinking tea with lemon caused a higher level of $\mathrm{Ni}$ in hair (2.2 times, Table 4). The consumption of yogurt resulted in a 2.4 times higher Ni level (Table 4). All these differences were statistically significant and all these factors were regarded as the second grouping variable. Although there were identified certain dietary factors that caused a higher level of metals in hair samples, this causal does not let itself be analyzed quantitatively.
Previously, Mikulewicz et al. [14] defined coefficients $\alpha_{\text {hair }}$ and $\beta_{\text {hair }}$ for the evaluation of bioavailability as the quotient (dimensionless value):

$\alpha_{\text {Hair }}=\frac{C_{\text {With appl }}}{C_{\text {Without appl }}}$

and the difference (expressed as $\mathrm{mg} / \mathrm{kg}$ ):

$\beta_{\text {Hair }}=C_{\text {With appl }}-C_{\text {Without appl }}$

where

$C_{\text {With appl }}$ The content of elements $(\mathrm{Cr}, \mathrm{Fe}, \mathrm{Ni})$ in hair of patients during orthodontic treatment

$C_{\text {Without appl }}$ The content of elements $(\mathrm{Cr}, \mathrm{Fe}, \mathrm{Ni})$ in hair of patients before the beginning of orthodontic treatment

In the present work, $\alpha$ coefficient (dimensionless, showing how many times the content increased vs. control sample) takes the following values after 4,8 , and 12 months of therapy, respectively: for $\mathrm{Cr}(9.1,8.9,7.9)$, for $\mathrm{Ni}(1.3,1.1,1.5)$, and for $\mathrm{Fe}(1.4,1.3,1.4)$. This shows that the content of $\mathrm{Cr}$ increased several times while the level of $\mathrm{Ni}$ and $\mathrm{Fe}$ only to a certain extent. The value of the coefficient was in all cases higher than 1 which signifies that the metal ions released from the appliance were transferred to hair tissue. $\beta$ coefficient (showing the increase in the content as expressed in $\mathrm{mg} / \mathrm{kg}$ ) was as follows: for $\mathrm{Cr}(0.16,0.16,0.14)$, for $\mathrm{Ni}(0.078,0.032$, $0.134)$, and for $\mathrm{Fe}(4.6,2.8,3.9)$. Since the coefficient $\beta$ reflects the difference in the content of metal ions between the samplings during the treatment and before the treatment, it indicated an increased content of $\mathrm{Cr}, \mathrm{Ni}$, and $\mathrm{Fe}$ in hair as a result of orthodontic treatment. This difference (expressed in $\mathrm{mg} / \mathrm{kg}$ ) was the highest for Fe because this is the major trace element and is the main component of stainless steel. For all the elements examined, the difference was higher than 0 , which shows the transfer of metal ions released from the

Table 4 The effect of dietary habits on contents of chromium and nickel in hair collected before treatment, $\mathrm{mg} / \mathrm{kg}$

\begin{tabular}{|c|c|c|c|c|c|c|c|c|c|}
\hline & & \multicolumn{4}{|l|}{$\mathrm{Cr}$} & \multicolumn{4}{|l|}{$\mathrm{Ni}$} \\
\hline & & Mean & $\mathrm{SD}$ & Median & $p$ & Mean & $\mathrm{SD}$ & Median & $p$ \\
\hline Tea with lemon & $\begin{array}{l}\text { Yes, } N=32 \\
\text { No, } N=15\end{array}$ & $\begin{array}{l}0.0190 \\
0.0226\end{array}$ & $\begin{array}{l}0.0423 \\
0.0460\end{array}$ & $\begin{array}{l}0.00100 \\
0.00100\end{array}$ & 0.882 & $\begin{array}{l}0.336 \\
0.150\end{array}$ & $\begin{array}{l}0.366 \\
0.156\end{array}$ & $\begin{array}{l}0.239 \\
0.111\end{array}$ & 0.009 \\
\hline Coca-Cola & $\begin{array}{l}\text { Yes, } N=21 \\
\text { No, } N=26\end{array}$ & $\begin{array}{l}0.0321 \\
0.0105\end{array}$ & $\begin{array}{l}0.0545 \\
0.0285\end{array}$ & $\begin{array}{l}0.00100 \\
0.00100\end{array}$ & 0.095 & $\begin{array}{l}0.300 \\
0.256\end{array}$ & $\begin{array}{l}0.410 \\
0.244\end{array}$ & $\begin{array}{l}0.185 \\
0.221\end{array}$ & 0.692 \\
\hline Yogurt & $\begin{array}{l}\text { Yes, } N=38 \\
\text { No, } N=9\end{array}$ & $\begin{array}{l}0.0200 \\
0.0212\end{array}$ & $\begin{array}{l}0.0437 \\
0.0426\end{array}$ & $\begin{array}{l}0.00100 \\
0.00100\end{array}$ & 0.572 & $\begin{array}{l}0.310 \\
0.131\end{array}$ & $\begin{array}{l}0.353 \\
0.056\end{array}$ & $\begin{array}{l}0.231 \\
0.144\end{array}$ & 0.068 \\
\hline Allergic to nickel & $\begin{array}{c}\text { Yes, } N=5 \\
\text { No, } N=42\end{array}$ & $\begin{array}{l}0.00828 \\
0.0216\end{array}$ & $\begin{array}{l}0.01627 \\
0.0451\end{array}$ & $\begin{array}{l}0.00100 \\
0.00100\end{array}$ & 0.641 & $\begin{array}{l}0.0820 \\
0.298\end{array}$ & $\begin{array}{l}0.0796 \\
0.336\end{array}$ & $\begin{array}{l}0.0832 \\
0.223\end{array}$ & 0.037 \\
\hline
\end{tabular}

Mann-Whitney $U$ test was used. Statistically significant at $p<0.1$ are presented in italic 
orthodontic appliance to hair tissue. On the basis of the evaluation of $\alpha$ and $\beta$ coefficients, hair mineral analysis seems to reflect the exposure to $\mathrm{Cr}, \mathrm{Fe}$, and $\mathrm{Ni}$ from orthodontic appliances. This can be observed in Fig. 2, where the baseline reflects $\alpha=1$ and $\beta=0$, which shows no transfer of metals to hair tissue.

\section{Conclusions}

The kinetics of metal ions released from orthodontic appliance and their transfer to hair tissue can be evaluated by a biomarker of chronic exposure, which is hair mineral analysis. The outcomes of the present study revealed that the content of $\mathrm{Cr}$ was statistically significantly higher during the treatment than before the beginning of therapy. However, the doses of released metal ions did not pose a toxicological danger.

Acknowledgments This research was financially supported by The National Centre for Research and Development in Poland (N R130006 10).

Conflict of Interest The authors declare no conflict of interest.

Ethical Standards The study was approved by the Ethical Committee of Wroclaw Medical University (KB-400/2010) and conducted in accordance with the Declaration of Helsinki. All patients signed a consent form.

Open Access This article is distributed under the terms of the Creative Commons Attribution License which permits any use, distribution, and reproduction in any medium, provided the original author(s) and the source are credited.

\section{References}

1. Brantley WA, Eliades T (2001) Orthodontic materials: scientific and clinical aspects. Georg Thieme, Stuttgart, pp 271-286

2. Kempson IM, Lombi E (2011) Hair analysis as a biomonitor for toxicology, disease and health status. Chem Soc Rev 40:3915-3940

3. Goullé JP, Mahieu L, Castermant J, Neveu N, Bonneau L, Lainé G, Bouige D, Lacroix C (2005) Metal and metalloid multi-elementary ICP-MS validation in whole blood, plasma, urine and hair. Reference values. Forensic Sci Int 153:39-44

4. Kusy RP (2002) Orthodontic biomaterials: from the past to the present. Angle Orthod 72:501-512

5. Hafez HS, Selim EMN, Eid FHK, Tawfik WA, Al-Ashkar EA, Mostafa YA (2011) Cytotoxicity, genotoxicity, and metal release in patients with fixed orthodontic appliances: a longitudinal in-vivo study. Am J Orthod Dentofacial Orthop 140:298-308
6. Al-Ashkar EA, Mostafa YA, Eliades T, Athanasiou AE (2002) In vivo aging of orthodontic alloys: implications for corrosion potential, nickel release, and biocompatibility. Angle Orthod 72:222-237

7. Mikulewicz M, Chojnacka K, Wołowiec P (2014) Release of metal ions from fixed orthodontic appliance: an in vitro study in continuous flow system. Angle Orthod 84:140-148

8. Ousehal L, Lazrak L (2012) Change in nickel levels in the saliva of patients with fixed orthodontic appliances. Int Orthod 10:190-197

9. Matos de Souza R, Macedo de Menezes L (2008) Nickel, chromium and iron levels in the saliva of patients with simulated fixed orthodontic appliances. Angle Orthod 78:345-350

10. Agaoglu G, Arun T, Izgi B, Yarat A (2001) Nickel and chromium levels in the saliva and serum of patients with fixed orthodontic appliances. Angle Orthod 71:375-379

11. Faccioni F, Franceschetti P, Cerpelloni M, Fracasso ME (2003) In vivo study on metal release from fixed orthodontic appliances and DNA damage in oral mucosa cells. Am J Orthod Dentofacial Orthop 124:687-694

12. Amini F, Borzabadi Farahani A, Jafari A, Rabbani M (2008) In vivo study of metal content of oral mucosa cells in patients with and without fixed orthodontic appliances. Orthod Craniofac Res 11:51-56

13. Amini F, Rakhshan V, Sadeghi P (2012) Effect of fixed orthodontic therapy on urinary nickel levels: a long-term retrospective cohort study. Biol Trace Elem Res 150:31-36

14. Mikulewicz M, Chojnacka K, Zielińska A, Michalak I (2011) Exposure to metals from orthodontic appliances by hair mineral analysis. Environ Toxicol Pharmacol 32:10-16

15. Gil F, Hernández AF, Márquez C, Femia P, Olmedo P, LópezGuarnido O, Pla A (2011) Biomonitorization of cadmium, chromium, manganese, nickel and lead in whole blood, urine, axillary hair and saliva in an occupationally exposed population. Sci Total Environ 409:1172-1180

16. Wołowiec P, Michalak I, Chojnacka K, Mikulewicz M (2013) Hair analysis in health assessment. Clin Chim Acta 419:139-171

17. Johnstone MA, Albert DM (2002) Prostaglandin-induced hair growth. Surv Ophthalmol 47:185-202

18. Levrini L, Lusvardi G, Gentile D (2006) Nickel ions release in patients with fixed orthodontic appliances. Minerva Stomatol 55: 115-121

19. Abtahi M, Jahanbin A, Yaghoubi M, Esmaily H, Zare H (2013) Are more nickel ions accumulated in the hair of fixed orthodontic patients? Indian J Dent Res 24:298-301

20. Martin-Cameán A, Molina-Villalba I, Jos A, Iglesias-Linares A, Solano E, Cameán AM, Gil F (2014) Biomonitorization of chromium, copper, iron, manganese and nickel in scalp hair from orthodontic patients by atomic absorption spectrometry. Environ Toxicol Pharmacol 37:759-771

21. Chojnacka K, Zielińska A, Górecka H, Dobrzański Z, Górecki H (2010) Reference values for hair minerals of Polish students. Environ Toxicol Pharmacol 29:314-319

22. Dongaría G, Lombardo M, Tamburo E, Varrica D, Cibella F, Cuttitta G (2011) Concentration and reference interval of trace elements in human hair from students living in Palermo, Sicily (Italy). Environ Toxicol 32:27-34

23. Vanaelst B, Huybrechts I, Michels N, Vyncke K, Sioen I, De Vriendt T, Flórez MR, Aramendía M, Balcaen L, Resano M, Vanhaecke F, De Henauw S (2012) Mineral concentrations in hair of Belgian elementary school girls: reference values and relationship with food consumption frequencies. Biol Trace Elem Res 150:56-67 